\title{
Perencanaan Abdimas Dalam Meningkatkan Motivasi Pengusaha Usaha Mikro Kecil Menengah (UMKM) di Kelurahan Tanjung Duren Jakarta Barat
}

Lidia Sandra ${ }^{1}$, Pinkan Margaretha ${ }^{2}$, Yasinta Astin Sokang ${ }^{3}$, Frieska Soplantila ${ }^{4}$, Bambang Siswanto ${ }^{5}$, Daniel Widjaja $^{6}$, Mina Sulastri $^{7}$, Dwi Aprillita ${ }^{8}$, Lambok Tampubolon $^{9}$, Subagyo $^{10}$

\author{
${ }^{1,2,3,4}$ Program Studi Psikologi,Universitas Kristen Krida Wacana \\ Jl. Tanjung Duren Raya No. 4 Jakarta Barat 11470 \\ ${ }^{1}$ lidia.sandra@ukrida.ac.id \\ 22pinkan.margaretha@ukrida.ac.id \\ 3astinsokang@ukrida.ac.id \\ ${ }^{4}$ frieska.soplantila@ukrida.ac.id \\ 5,6,7,8 Program Studi Manajemen,Universitas Kristen Krida Wacana \\ Jl. Tanjung Duren Raya No. 4 Jakarta Barat 11470 \\ 5bambang.siswanto@ukrida.ac.id \\ 6daniel.widjaja@ukrida.ac.id \\ ${ }^{7}$ mina.sulastri@ukrida.ac.id \\ ${ }^{8}$ lita@ukrida.ac.id \\ ${ }^{9,10}$ Program Studi Akuntansi,Universitas Kristen Krida WacanaJakarta \\ Jl. Tanjung Duren Raya No. 4 Jakarta Barat 11470 \\ ${ }^{9}$ lambok.tampubolon@ukrida.ac.id \\ ${ }^{10}$ subagyo@ukrida.ac.id
}


Abstrak - Hal yang penting untuk pengembangan diri adalah motivasi. Untuk dapat melakukan hal besar dibutuhkan motivasi yang kuat, di mana tidak dapat dilakukan dalam keadaan biasa. Agar motivasi tetap efektif, perlu ada disiplin yang tinggi dan konsistensi dalam menjalankannya sesuai rencana dalam mencapai yang diinginkan, namun tetap menghormati norma-norma dan aturan-aturan yang ada. Memiliki pandangan positif serta keinginan untuk melangkah lebih maju dapat membantu menghilangkan rasa takut dan rasa ragu. Hal-hal semacam ini perlu diterapkan dan ditularkan kepada masyarakat sektor bidang Usaha Mikro Kecil Menengah (UMKM) untuk membantu mereka agar usaha yang mereka geluti dapat bertahan dan berkelanjutan serta menjadi sukses dan dikenal oleh masyarakat luas. Fakultas Psikologi dan Fakultas Ekonomi dan Bisnis UKRIDA merasa memiliki tanggung jawab sosial untuk memberi kontribusi demi keberlangsungan UMKM di sekitar UKRIDA untuk dapat terus bertahan. Kegiatan ini dilakukan melalui pelatihan dan pendampingan yang berkaitan dengan motivasi UMKM agar bangkit kembali, mendampingi pengurusan izin usaha, serta melatih UMKM untuk menggunakan teknologi agar meningkatkan penjualan produknya. Tujuan kegiatan ini adalah untuk membantu mendukung program Pemerintah yang berupaya membangkitkan kembali Usaha Mikro Kecil Menengah dan memenuhi salah satu tugas Tridharma perguruan tinggi yakni pelaksanaan pengabdian kepada masyarakat.

Kata kunci-motivasi, teknologi, Tridharma, UMKM.

Abstract - One of the important things for self-development is motivation. To do great things requires a powerful motivation, which we not usually find in ordinary circumstances. In order for motivation to remain effective, there are needs to be discipline and consistent in achieving the goals, but still respecting the existing norms and rules. Having a positive outlook and a desire to move forward can help eliminate fear and doubt. For the Micro, Small and Medium Enterprises (MSME) sector, this kind of motivation is crucial in helping them to survive and to sustain the business. In the long run, they can be successful and widely known by the community. The Faculty of Psychology and the Faculty of Economics and Business UKRIDA feel the social responsibility to contribute to the sustainability of MSMEs around UKRIDA to continue to survive. We carry this activity through training and mentoring related to the motivation of MSMEs to get back up, help get business permits, and training MSMEs to use technology to increase product sales. This activity helps support Government programs to revive Micro, Small and Medium Enterprises and fulfill one of the Tridharma tasks of higher education, namely the implementation of community service.

Keywords-motivation, technology, Tridharma, MSMEs .

\section{PENDAHULUAN}

Usaha Mikro Kecil dan Menengah (UMKM) memiliki peran strategis dan kontribusi yang sangat besar bagi perekonomian nasional sebagai penyumbang Produk Domestik Bruto (PDB) di negara Indonesia lebih dari $50 \%$. Sesuai Undang-Undang Nomor 20 Tahun 2008 tentang Usaha Mikro Kecil dan Menengah, dimana Usaha Mikro merupakan usaha produktif milik perorangan dan/atau badan usaha perorangan yang memenuhi kriteria Usaha Mikro dengan asset maksimal 50 juta dan omzet sebesar 300 juta, Usaha Kecil memiliki kriteria asset sebesar 50-500 juta dengan omzet sebesar 300 juta-2,5 milyar, sedangkan Usaha Menengah memiliki kriteria 500 juta-10 milyar dengan omzet sebesar 2,5-50 milyar sebagaimana diatur dalam Undang-Undang tersebut. [1]

Menjadi seorang wirausaha perlu dilatih. Agar menjadi seorang wirausaha yang berhasil perlu ada pengetahuan dan arahan yang jelas. Semangat dan cita-cita saja tidak cukup. Tidak memiliki relasi, kurang memiliki pengetahuan tentang bisnis, tidak memiliki perencanaan yang matang, tidak memiliki pengalaman dapat menjadikan kegagalan dalam membuka usaha.[2]

UMKM dapat dikatakan sebagai jantung perekonomian Indonesia karena sektor inilah yang menggerakkan perekonomian yang ada di Indonesia. Namun sejak adanya Pandemi Covid-19, sektor UMKM mengalami banyak hambatan dan tantangan.[3] Dikatakan oleh Presiden RI Bapak Jokowi bahwa diharapkan agar sektor UMKM dapat bertahan dan bekerja lebih keras dari sebelumnya, diharapkan semangatnya jangan kendur.[4] Sangat tidak mudah untuk membuat suatu usaha maju dan bangkit kembali. Dalam menghadapi kendala biasanya kita akan kehilangan fokus dan motivasi. [3] Padalah motivasi adalah merupakan satu hal yang sangat penting, dimana motivasi adalah merupakan kekuatan atau daya dorong yang menggerakkan kehendak untuk mencapai tujuan yang kita kehendaki. [5]

Tak jarang sebagai manusia akan mengalami saat-saat kekurangan motivasi. Motivasi harus kita munculkan dari dalam diri sendiri. Tanpa motivasi sulit bagi kita untuk mencapai apa yang kita inginkan.[6] Motivasi diri sendiri adalah kemampuan untuk melakukan apa yang perlu dilakukan, tanpa pengaruh orang lain ataupun situasi tertentu. Ciri individu yang memiliki motivasi diri adalah mereka yang tanpa menyerah atau membutuhkan pihak lain untuk menyemangati di dalam menyelesaikan tugas karena mampu menemukan alasan dan kekuatan. Kemampuan untuk menyemangati diri sendiri yang muncul dari dalam hati biasanya terlahir berupa tekad dari motivasi yang konstan.[7] Tidak mudah menyerah ketika permasalahan menghadang di depan kita, tetapi kita hadapi agar kita menjadi tangguh.[6]

Membangun motivasi di dalam diri sendiri adalah hal yang tidak mudah. Banyak di antara kita yang mungkin tidak mengetahui bagaimana cara membangun motivasi di dalam diri sendiri.[8] Demikianpun halnya dengan UMKM yang berada di lingkungan daerah kelurahan Tanjung Duren 
dengan lokasi dekat dengan area Kampus Universitas Kristen Krida Wacana (UKRIDA). UMKM harus terus berkarya di masa Pandemi Covid-19 melalui inovasiinovasi produknya. Tidak mudah untuk melakukan hal tersebut, kalau tidak diimbangi dengan keuletan dan ketangguhan serta semangat yang kuat. UMKM harus memiliki terobosan-terobosan baru agar UMKM dapat menjadi sukses kembali. [9] Fakultas Psikologi (FPSi) dan Fakultas Ekonomi dan Bisnis (FEB) UKRIDA merasa memiliki tanggung jawab sosial memberikan kontribusi demi keberlangsungan Usaha Mikro Kecil Menengah untuk dapat terus bertahan melalui pelatihan dan pendampingan yang berkaitan dengan motivasi UMKM agar bangkit kembali, mendampingi pengurusan izin usaha, serta melatih UMKM untuk menggunakan teknologi agar meningkatkan tingkat penjualan produknya. Pemberian motivasi bagi UMKM perlu dilakukan agar usahanya dapat berkembang pesat.[10] Dibutuhkan konsistensi dan pemasaran yang baik dalam menjalankan usahanya agar hasil dapat mudah diraih.[11] Diharapkan dengan adanya pelayanan kegiatan pengabdian kepada masyarakat yang akan dilakukan oleh 2 (dua) kolaborasi Fakultas yang ada di UKRIDA, selain bermanfaat dan berfaedah, UKRIDA juga telah ikut mendukung program Pemerintah yakni Gerakan Masyarakat (GERMAS). Selain itu, UKRIDA telah melakukan salah satu kewajiban Tridharma Perguruan Tinggi melalui implementasi pengabdian kepada masyarakat (Abdimas).

UKRIDA akan menyusun time schedule rancangan kegiatan pengabdian kepada masyarakat secara bertahap untuk pelaksanaan secara teknis sebagai ujud nyata implementasi pelaksanaan pengabdian kepada masyarakat bagi Usaha Mikro Kecil dan Menengah (UMKM).

\section{METODE PELAKSANAAN}

Rencana pelaksanaan implementasi kegiatan pengabdian kepada masyarakat mengenai pemberian motivasi bagi sektor Usaha Mikro Kecil Menengah (UMKM) adalah sebagai berikut:

\section{A. Koordinasi dengan Kelurahan Tanjung Duren}

- Melakukan penjajagan awal dengan Kelurahan (Bapak Iskandar) yang dipelopori oleh salah satu Tim Abdimas (Bapak Dr. Lambok Tampubolon) untuk mempertemukan Tim Kolaborasi dari 2 Fakultas (Fakultas Psikologi (FPsi) dan Fakultas Ekonomi dan Bisnis (FEB UKRIDA) dengan tokoh masyarakat (Bapak Sudradjat).

- Mempersiapkan surat permohonan yang ditujukan kepada bapak Lurah Tanjung Duren dan menyampaikan permohonan untuk melakukan Focus Group Discussion (FGD).
- FGD dengan bapak Lurah untuk mendapatkan arahan dan menentukan serta penunjukkan mana UMKM yang perlu mendapat pendampingan dan pelatihan dari Tim Abdimas UKRIDA.

\section{B. Observasi}

Fakultas Psikologi (FPsi) Fakultas Ekonomi dan Bisnis (FEB) melakukan observasi awal dengan mengunjungi UMKM yang tutup yang tidak jauh dari lingkungan UKRIDA, dengan menanyakan UMKM yang berada di dekatnya yang masih tetap buka, untuk mengetahui UMKM tersebut tidak melakukan aktivitas kegiatan berjualan.

UMKM di sekitar Kelurahan Tanjung Duren ini sebenarnya memiliki potensi yang baik karena lokasi ini berdekatan dengan lokasi kost-kost mahasiswa yang berpotensi untuk memenuhi kebutuhan mahasiswa sehari-hari, karena kebanyakan UMKM ini adalah di sektor bidang kuliner.

Hal ini sangat disayangkan apabila usaha tersebut harus berhenti, karena selain peluang UMKM dalam mengurangi tingkat pengangguran, juga berpeluang tinggi memajukan perekonomian negara, sehingga perlu ada usaha dan upaya untuk mendorong kembali UMKM dapat amelakukan aktivitasnya.

\section{Rencana Pemberian Edukasi}

Rencana memberikan pelayanan pengabdian kepada masyarakat ini dalam bentuk edukasi yang akan disampaikan kepada UMKM yang mengalami dampak akibat Pandemi sehingga perlu diberikan motivasi kembali agar mereka bangkit kembali untuk memulai kembali usahanya.

Agar pelaksanaan kegiatan menjadi lebih baik dan efektif, Tim Abdimas UKRIDA akan menyiapkan tim yang terdiri dari mahasiswa, dengan tujuan agar pada saat pelaksanaan tim mahasiswa dapat membantu dan merespon peserta yang mengajukan pertanyaan. Selain daripada itu bagi mahasiswa itu sendiri mereka akan memiliki pengalaman dalam berinteraksi dengan masyarakat langsung.

\section{HASIL PEMBAHASAN}

Tahapan-tahapan persiapan rencana kegiatan pengabdian kepada masyarakat yang akan dilakukan :

\section{A. Focus Group Discussion (FGD)}




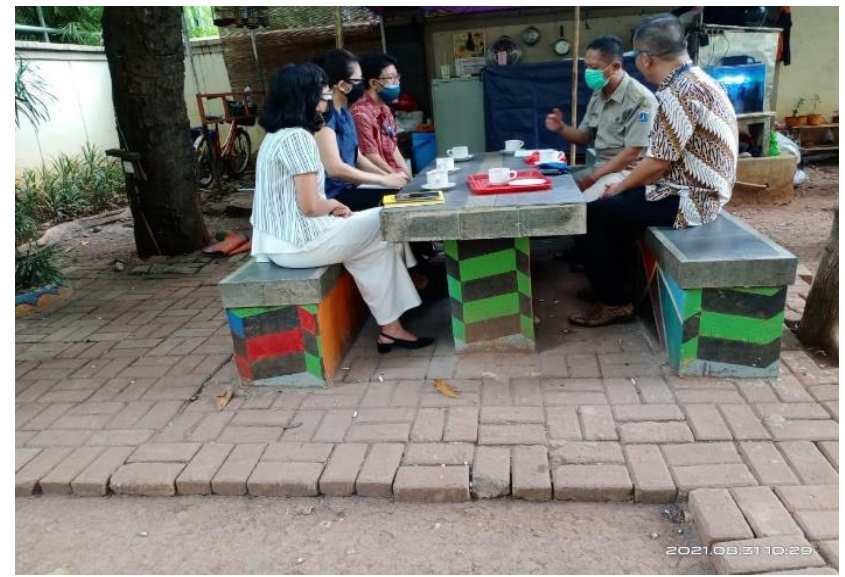

Gambar 1. Pertemuan dengan Bapak Lurah Tanjung Duren

Dalam pertemuan antara Bapak Lurah dan Tim Abdimas UKRIDA ini disampaikan bahwa Fakultas Psikologi (FPsi), bersama dengan Fakultas Teknik dan Ilmu Komputer (FTIK), dan Fakultas Ekonomi dan Bisnis (FEB) UKRIDA bermaksud untuk mengadakan kegiatan pengabdian kepada masyarakat bagi Usaha Mikro Kecil Menengah (UMKM) dengan berfokus selain mengenai edukasi motivasi oleh Fakultas Psikologi, tetapi juga mengenai pemanfaatan teknologi melalui pemberian pelatihan oleh Fakultas Teknik dan Ilmu Komputer, serta memberikan pendampingan untuk pengurusan izin usaha.

Disampaikan oleh Bapak Lurah bahwa Tim Abdimas UKRIDA akan dibantu oleh Bapak Suroso bidang Ekonomi dan Perbankan dan salah satu Tokoh Masyarakat yang mempunyai pengaruh besar dalam komunitas masyarakat Tanjung Duren Bapak Sudradjat, hasil pertemuan ini dapat dilihat pada gambar 2 di bawah ini.

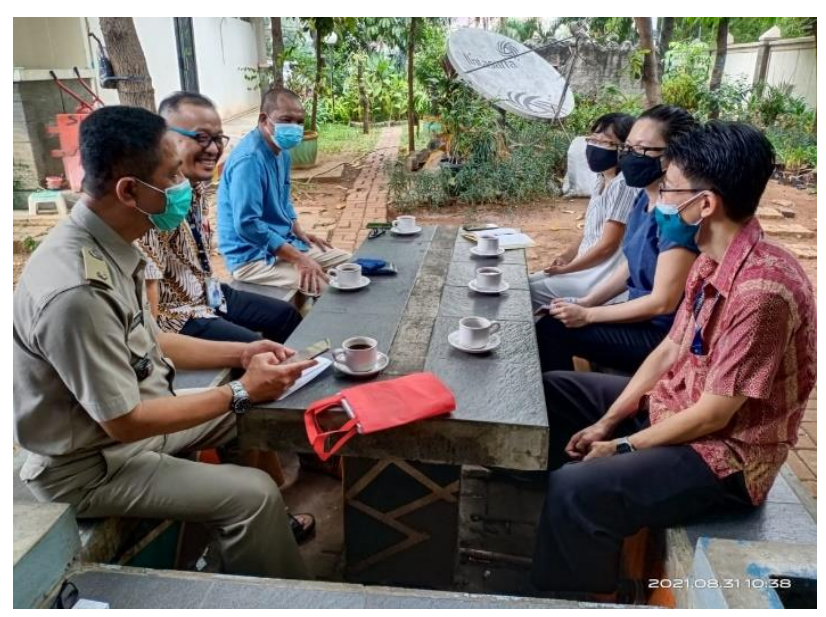

Gambar 2. Pertemuan Tim Abdimas UKRIDA, Bapak Lurah Tanjung Duren (Bapak Iskandar) dan Tokoh Masyarakat (Bapak Sudradjat)

\section{B. Hasil Observasi Lapangan :}
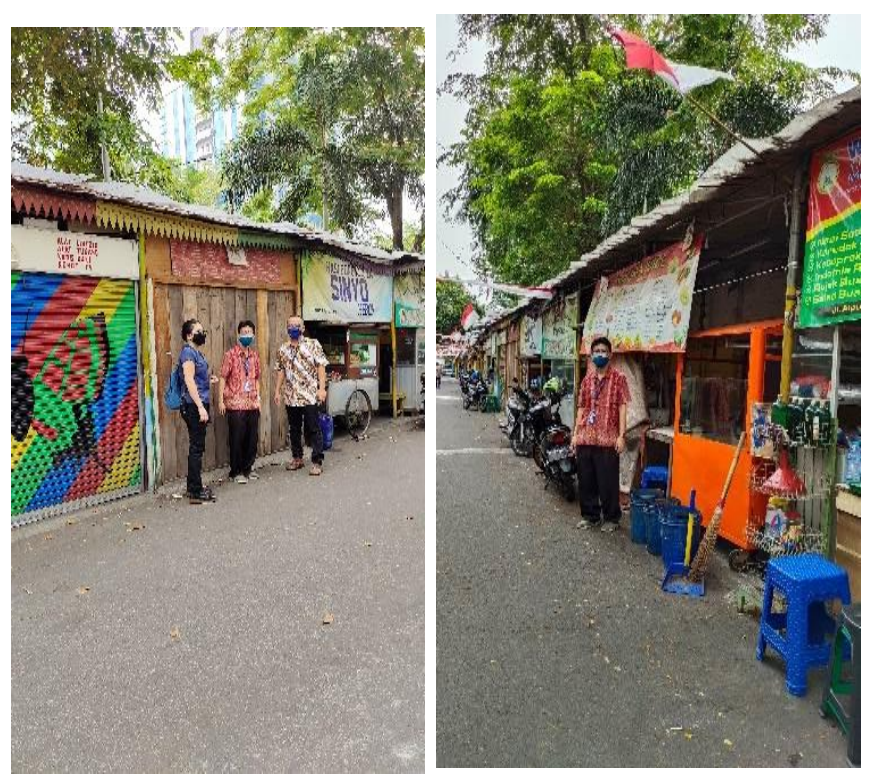

Gambar 3. Beberapa UMKM yang tutup di masa Pandemi

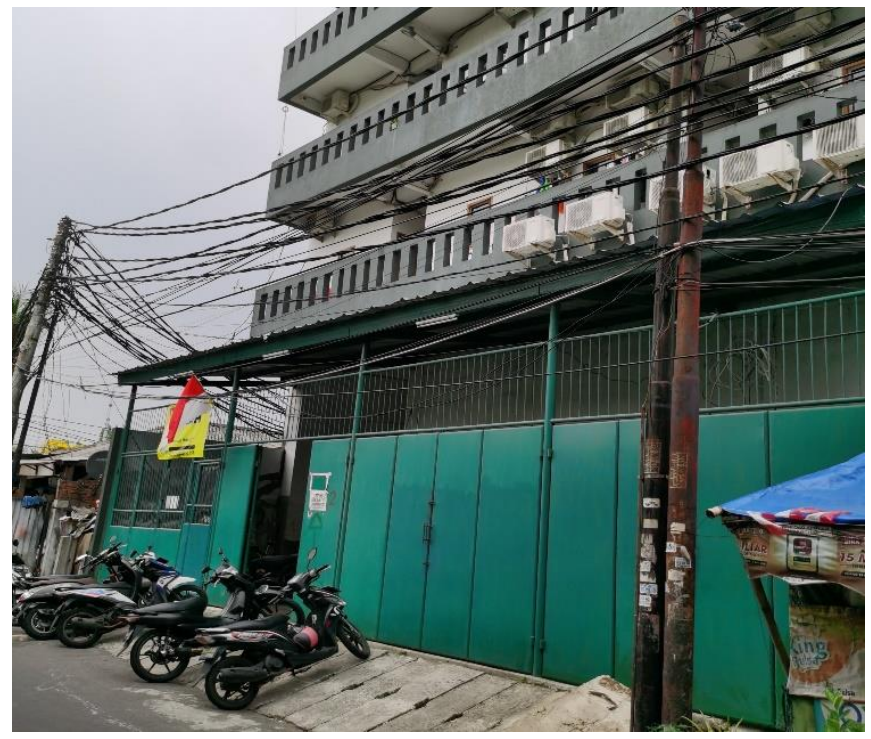

Gambar 4. Tempat Kost berada di daerah UMKM Tanjung Duren 


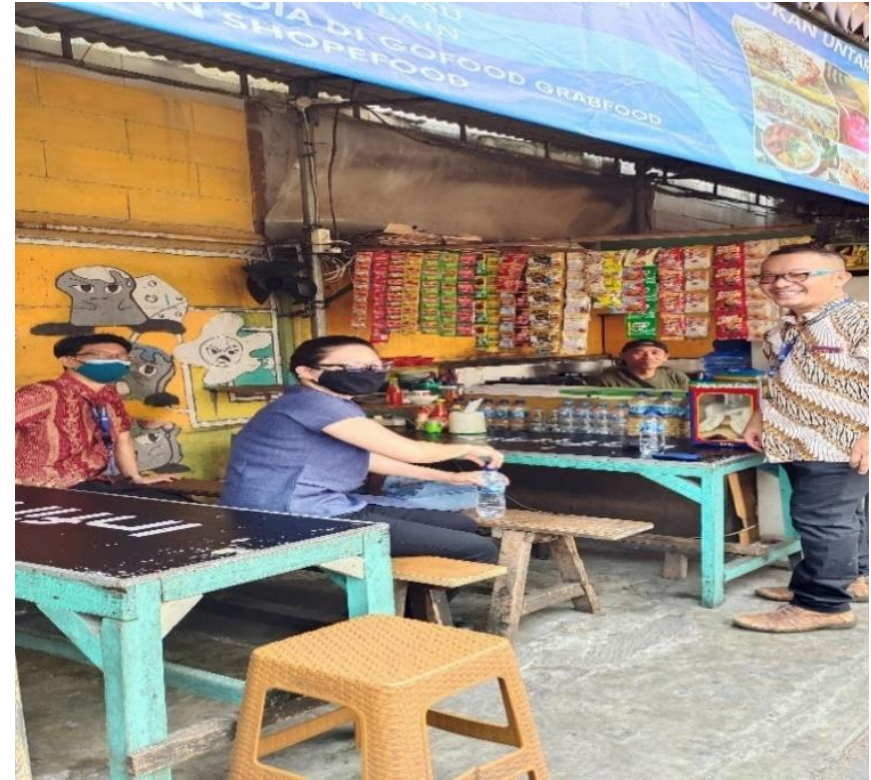

Gambar 5. Tim Abdimas berdiskusi dengan pemilik UMKM

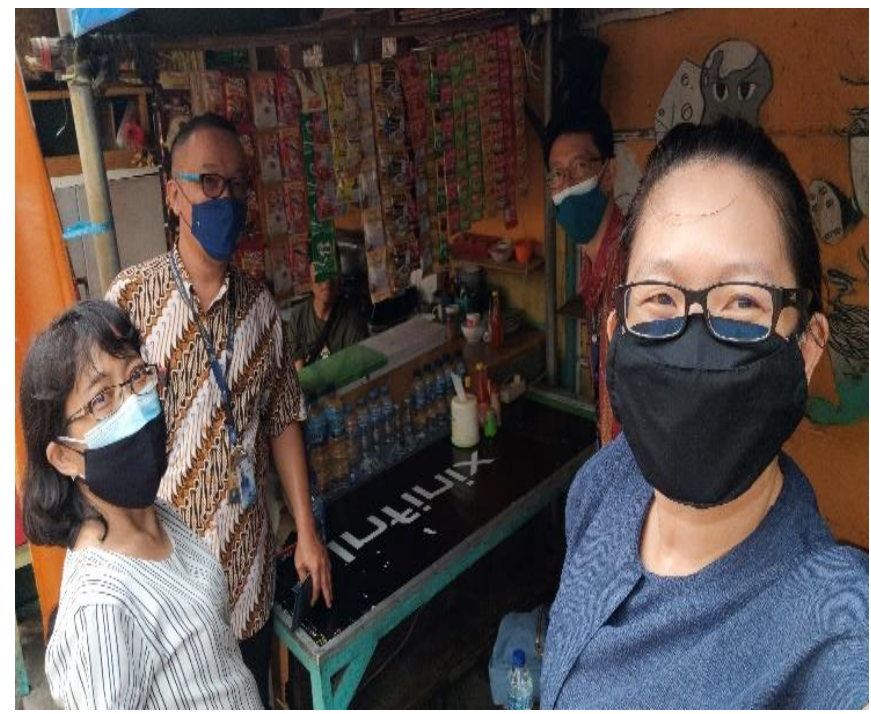

Gambar 6. Selesai berdiskusi dengan pemilik UMKM yang masih buka di masa Pandemi

Dalam survey dan observasi terlihat beberapa hasil observasi pemantauan sementara Tim Abdimas UKRIDA, adanya tempat kost di sekitar UMKM yang dapat dilihat dalam gambar 4, dimana tempat kost ini berpeluang sebagai customer yang kebyakan adalah mahasiswa dan ada beberapa karyawan/pekerja yang pasti memerlukan UMKM dalam memenuhi kebutuhan sehari-harinya. Dalam pengamatan survey Tim Abdimas UKRIDA terlihat pula bahwa ada beberapa UMKM di area Tanjung Duren yang akan menjadi subyek pelaksanaan Abdimas terlihat tutup, dan Tim Abdimas berdiskusi dengan pemilik UMKM yang masih buka pada saat Pandemi untuk menanyakan beberapa UMKM yang tutup sampai saat ini, dan dapat dilihat dalam gambar 5 dan gambar 6 .

\section{Persiapan Intern}

- Desain Flyer dan Spanduk.

Tim Abdimas akan mempersiapkan contoh flyer yang nantinya sekaligus dijadikan undangan dan disebarkan kepada UMKM tentang rencana kegiatan edukasi tersebut. Spanduk akan dirancang untuk digunakan pada hari $\mathrm{H}$.

- Persiapan Materi untuk Pertemuan.

Materi akan dipersiapkan oleh Tim Pakar Fakultas Psikologi dengan menggunakan bahasa sederhana agar mudah dipahami oleh peserta UMKM.

- Persiapan Tim Penyelanggara Teknis di lapangan. Dalam mempersiapkan pelaksanaan kegiatan ini, Tim Abdimas akan melibatkan beberapa mahasiswa untuk membantu pelaksanaan pada hari $\mathrm{H}$.

\section{IV.KESIMPULAN}

Perencanaan kegiatan pelayanan pengabdian kepada masyarakat bagi UMKM Kelurahan Tanjung Duren sebagai berikut :

1. Perlu dibangun kembali motivasi diri bagi UMKM yang telah menurun akibat dampak Pandemi Covid19.

2. Perlu adanya pendampingan untuk pengurusan izin usaha karena adanya UMKM yang benar-benar masih awam tidak memiliki pengetahuan bagaimana cara mengurus izin usaha.

3. Perlu adanya pelatihan penggunaan pemanfaatan teknologi agar hasil produk mereka dapat lebih dari penjualan offline.

\section{UCAPAN TERIMA KASIH}

Ucapan terima kasih kepada Bapak Lurah Tanjung Duren (Bapak Iskandar) yang telah memberikan kesempatan bagi Tim Kolaborasi Fakultas UKRIDA untuk melakukan kegiatan pengabdian kepada maysarakat.

Ucapan terima kasih kepada Bapak Tokoh Masyarakat Tanjung Duren (Bapak Sudradjat) atas kehadirannya dalam Focus Group Discussion (FGD).

Ucapan terima kasih kepada Ibu Rektor UKRIDA (Dr. dr. Wani Gunardi, Sp.MK (K) yang telah mendukung dan memberikan kesempatan bagi Tim FPsi dan FEB UKRIDA melakukan kegiatan pengabdian kepada masyarakat di area Tanjung Duren. 
Ucapan terima kasih kepada Dekan FPsi (Bapak Dr. Stefanus Sandjaja) dan Dekan FEB (Ibu Dr. Melitina) UKRIDA yang telah mendukung agar terlaksana kegiatan pengabdian kepada masyarakat ini dapat terselenggara.

Ucapan terima kasih kepada Tim Lembaga Penenelitian dan Pengabdian kepada Masyarakat UKRIDA yang memfasilitasi sehingga kegiatan ini akan berjalan sesuai rencana.

Ucapan terima kasih kepada pak Yos (UBK 3) dan ibu Tati (TU FEB) yang telah membantu dalam persiapan yang diperlukan oleh Tim Abdimas.

\section{DAFTAR PUSTAKA}

[1] "Meningkatkan Motivasi Umkm Dalam Menerapkan Pemasaran Online Komunitas UMKM Naik Kelas Kabupaten Bogor," [Online]. Available:

http://news.bsi.ac.id/meningkatkan-motivasi-umkm-dalammenerapkan-pemasaran-online-komunitas-umkm-naikkelas-kabupaten-bogor/.

[2] B. I. Pradana and R. Safitri, "Pengaruh Motivasi Wirausaha dan Mental Wirausaha terhadap Minat Wirausaha," Iqtishoduna, vol. 16, no. 1, pp. 73-82, 2020, doi: 10.18860/iq.v16i1.6797.

[3] "5 Cara Tetap Memiliki Motivasi Usaha Dalam Menjalankan UMKM," [Online]. Available: https://majoo.id/blog/detail/5-cara-agar-tetap-memilikimotivasi-usaha-dalam-menjalankan-umkm.

[4] "Jokowi Motivasi Pelaku UMKM yang Terdampak Covid19 (Tempo)," [Online]. Available: https://nasional.tempo.co/read/1391375/jokowi-motivasipelaku-umkm-yang-terdampak-covid-19/full\&view=ok.

[5] "Motivasi Diri," [Online]. Available: http://ueu6019.weblog.esaunggul.ac.id/2014/01/04/motivas i-diri/.

[6] "Memunculkan Motivasi Dalam Diri, Capai Kesuksesan," [Online]. Available:

https://www.itb.ac.id/berita/detail/3225/memunculkanmotivasi-dalam-diri-capai-kesuksesan.

[7] "Motivasi Diri Sendiri Kunci Sukses Bangkit dari Kegagalan," [Online]. Available: https://ajaib.co.id/motivasi-diri-sendiri-kunci-suksesbangkit-dari-kegagalan/.

[8] "Cara Menumbuhkan Motivasi yang Kuat dalam Diri," [Online]. Available: http://id.stie-stmy.ac.id/halkomentar146-cara-menumbuhkan-motivasi-yang-kuat-dalam71.html.

[9] "Motivasi Usaha Bagi UMKM Dimasa Pandemi COVID19," [Online]. Available: https://probolinggokab.go.id/motivasi-usaha-bagi-umkmdimasa-pandemi-covid-19/.

[10] "PENTINGNYA PEMBERIAN MOTIVASI BAGI UMKM," [Online]. Available: https://www.belitungtimurkab.go.id/?p=5005.

[11] "Yana Berikan Tips dan Motivasi Bagi Pelaku UMKM," [Online]. Available:

https://humas.bandung.go.id/berita/yana-berikan-tips-danmotivasi-bagi-pelaku-umkm. 